\title{
A Tale of Two Regions: \\ Comparative versus Competitive Approaches to Economic Restructuring ${ }^{\mathrm{i}}$ \\ Holli Thomas, Andrew Beer ${ }^{\mathrm{ii}}$ and David Bailey ${ }^{\mathrm{iii}}$
}

\begin{abstract}
In April 2004 Mitsubishi announced the closure of its Lonsdale plant in South Australia. Almost a year later, MG Rover went into administration, resulting in the immediate closure of its Longbridge plant just outside Birmingham, England. Both closures were expected to have a considerable impact on their regional economies through the loss of employment and associated economic activity. However, governments in Australia and England responded in significantly different ways: in England the focus was on competitive advantage through the modernisation of the auto cluster and the diversification of the regional economy into new, high-technology industries. In Australia, the national and State Governments introduced policy responses based on the pursuit of comparative advantage. This paper compares and contrasts the two sets of government responses and examines the capacity of each to deliver long term benefits to their affected communities.
\end{abstract}

\section{INTRODUCTION}

Forced redundancy through the closure of a large scale manufacturing plant presents a significant challenge for governments and communities. Such closures threaten the livelihoods of hundreds - if not thousands - of households; may depress the demand for goods and services within the region; place greater strain on public sector resources as well as other service providers; and, may call into question the financial credibility of governments (Spoehr, 2005). It is inevitable, therefore, that governments respond to large scale redundancies, particularly in highly visible industries such as the automotive sector. How they react and the outcomes they seek to achieve, vary according to the philosophies of government they espouse, the relative prosperity of their economies, the governance arrangements in place at that time; and, competing priorities within both the economy and system of government. A critical issue is the balance between centralised and regional responses to industry restructuring, with some governments favouring 'top down' responses, while others seek to empower actors at the regional or local level. Importantly, how governments choose to respond provides insights into the wider policy environment and the manner in which economic policy departments interpret, and interact with, the market economy.

Contemporary approaches to economic development at the regional scale draw upon two competing intellectual traditions. Much economic development theory and practice (see Armstrong and Taylor, 2000) draws upon the conceptual legacy first popularised by Ricardo (1817) around the economics of comparative advantage. The theory of comparative advantage posits that trade between nations generates greater levels of productivity for all parties, resulting in higher incomes and levels of wellbeing. From this perspective, regions should focus their economies on those industries and activities in which they have an advantage relative to others because of natural resource endowments, human capital or other factors. More recently, attention has focussed on the issue of 
sustainable competitive advantage which, according to Porter (1990), is the position a firm occupies when the above average profits it enjoys cannot be reproduced by competitors because they reflect advantages intrinsic to the firm. These advantages could include products that are differentiated from their competitors, or the establishment of a superior brand or reputation. Alternatively, sustainable competitive advantage could arise from the businesses environment in which the firm operates. Porter's (1990) ideas have infiltrated the policies and practice of regional development in the form of 'cluster' theory (Haughton, et al 2003; Ffowcs-Williams, 2004) with governments and other agencies responsible for the development of regions seeking to establish sustainable competitive advantage through improvements to human capital (the skill sets of workers), the establishment of agglomeration economies and by developing the capacity of firms within the region to collaborate and innovate. Indeed, innovation is seen to be central to developing competitive advantage which in turn is held up as essential for sustaining advanced economies (Porter, et al 2000), especially at the regional scale (Cooke and Morgan, 2000; Roberts and Enright, 2004). Innovation is argued to generate 'long-run upward development' (Courvisanos, 2003) by encouraging capital formation that is inherently place dependent or embedded. This perspective on the growth of regions therefore emphasises endogenous, rather than exogenous, development; a focus on enhancing the capacity of regions in working for further economic opportunities; the building of skills and intellectual capital within the region; and, the provision of appropriate infrastructure that advances the competitive position of the region.

Economic and industrial policies based on the achievement of comparative advantage can be viewed as reactive or responsive, while policies focussed on competitive advantage are more pro-active and forward looking. A pro-active policy built around developing competitive advantage, as Jacquemin (1987 in Oughton, 1997) notes, considers strategies which 'deliberately influence the transformation and the industrial reorganization of sectors, and nations', noting that 'in many sectors comparative advantages are based on partially controllable elements' (our italics). He points to policies that might alter the accumulation of physical and human capital over time, which in turn might alter relative capital endowments. In line with the European Commission, the Department of Trade and Infrastructure (DTI) in the UK has stressed that 'competitiveness increasingly relies on a country's appropriate structures of roles, institutions and processes to enable, organise, and drive efforts to improve business environment and clusters' (Porter and Ketels, 2003). Meanwhile, Porter has emphasised the regional scale in such a process: 'competitive advantage is created and sustained through a highly localized process' where 'national competitive advantage... resides as much at the level of the cluster as it does in individual industries' (Porter 1998a).

How governments respond to the closure of large scale manufacturing enterprises can be assessed with reference to the competing intellectual legacies of comparative advantage and competitive advantage. Policy responses that look to external solutions, that do not 'privilege' the affected region over others and which assume that an economy-wide process of adjustment will ensue, clearly draw upon the theory of comparative economic advantage. Approaches that are focussed more tightly on the needs of the affected region, which seek to encourage innovation within the region's firms and which concentrate on 'adding value' to affected workers within the region are consistent with an interpretation 
of growth dynamics that reflects notions of competitive advantage. It is also useful to note that over-reliance on a 'comparative advantage' approach in the context of a resource and mineral rich environment carries with it the risk of 'Dutch disease' effects which in turn damages manufacturing. This would seem especially pertinent in contemporary Australia given the volume of raw material exports and the strength of the Australian dollar. The 'Dutch disease' is a term originally used as shorthand for theories intended to explain how a favourable boost to one export sector had a negative impact on other export sectors. In the case of the Netherlands, this was the discovery and production of natural gas, whereas in the UK in the 1980s it was the effect of North Sea oil coming onstream that arguably led to the over-appreciation of sterling and the hollowing out of the manufacturing base (see Buiter and Miller, 1981; Eastwood and Venables 1982; Neary and Van Wijnbergen, 1984). In the case of Japan in the 1990s, Ozawa has argued that a long term industrial policy which built up some sectors whilst sheltering others led to lop-sided trade surpluses, sustained Yen appreciation and ultimately the hollowing out of the economy (Bailey and Sugden, 2007).

The remainder of this paper examines the policy responses used by governments in England and Australia to the loss of jobs in the automotive sector against these two models of understanding regional growth. The paper first examines the response of the UK government to the closure of MG Rover before examining Australian responses to redundancies at Mitsubishi Motors Australia Ltd (MMAL). The paper then compares the two sets of responses and the light they shed on the broader paradigms of government in each nation.

\section{POLICY RESPONSES TO THE ROVER CRISIS IN THE UK INDUSTRIAL POLICY AND COMPETITIVENESS}

The response of Government in the UK to the near collapse of Rover in 2000 and the eventual closure of MG Rover at Longbridge in 2005 must be understood in the context of broader industrial policy developed throughout the 1990s (DTI, 1994; 1995). In a series of White Papers the Department of Trade and Industry (DTI) placed competitiveness at the centre of industrial policy in Britain. Upon coming to power, Blair's 'new' Labour Party embraced this approach and launched its own Competitiveness White Paper in 1998. Competitiveness under the Blair Labour Government came to be seen as productivity growth (Bailey, 2003 p. 68). Industry policy was focused on policies that would raise productivity, including investment in technology and innovation, the promotion of small firms with growth potential, and a more significant focus on 'soft' support such as advisory services, education and training, collaborative arrangements and fostering networks and clusters (Wren, 2001; Gavron, et al 1998). While the 1998 White Paper continued to emphasise competitiveness in terms of productivity, it also placed an increased importance on the role of the 'knowledge economy'. The 1998 White Paper states that firms have to 'compete by exploiting capabilities which competitors find hard to imitate, arguing that 'the UK's distinctive capabilities are not raw materials, land or cheap labour [but] knowledge, skills and capabilities' (DTI, 1998 p.6). Influenced by Porter (1990; 1998a and b) the British Government supported clusters as a way to promote a knowledge economy and thereby encourage competitiveness. 
The emphasis on 'spatial clusters' meant that a regional response became a vital dimension of competitive advantage (Porter 1990, 2003). It led to a decentralisation of industrial policy to the regional level and the creation of Regional Development Agencies (RDAs), who were seen as key agents for implementing competitiveness programmes. The role of the RDAs, in relation to the White Paper was to 'encourage the exploitation of the science and engineering base; develop links between business and higher education; co-ordinate the development and implementation of innovation and technology programmes; and to disseminate best practice' (Wren, 2001 p.853). The regional level was seen as the most effective level for government intervention and economic management, with support focused on 'clusters of inter-linked sectors with agencies supposedly taking a systemic approach and with the emphasis shifting towards the provision of 'soft support' required by firms' (Bailey, 2003 p.69)

The broader context of industry policy in the UK is fundamental in understanding the Government's response to the Rover crisis, especially its focus on developing competitive advantage by modernising the auto cluster and diversifying the regional economy. The decentralisation of industrial policy meant that the Advantage West Midlands (AWM) regional development agency played a central role. Advantage West Midlands established economic development strategies which reflected the focus on competitiveness enunciated in the 1998 Competitiveness White Paper and did so through an explicit clusters framework. This was evident in the Regional Innovation Strategy and the West Midlands Economics Strategy. The RIS placed competitive advantage through innovation at the centre of AWMs strategy for regional development, stating 'in today's global economy businesses gain competitive advantage by constantly innovating...innovation is profitable change that arises as a result of the exploitation of new ideas' (RIS, 1998 p.2).

The UK Government responded to BMW's announcement that it intended to sell substantial parts of the Rover Group by establishing a Rover Task Force (RTF1) that brought together local actors under the leadership of the Regional Development Agency (RDA). The government recognised the crisis that would have befallen the region had Rover closed and the Rover Task Force was established to minimise the damage should the manufacturer close in the future. The Taskforce received considerable funding during this period, the 1129 million that had been allocated to BMW as a subsidy for production at Longbridge under the Regional Selective Assistance (RSA) programme was instead allocated to the RTF. From 2002 to 2005 funding was provided to the Taskforce to safeguard the 24,000 jobs at risk should the Longbridge plant close (Armstrong, 2006 p.9). The Rover Task Force focused on modernising the auto cluster and diversifying the supply chain that was dependent on Rover into other sectors.

\section{Modernising and Diversifying the Automotive Cluster}

The RTF1 recognised that modernisation of the auto 'cluster' was crucial as the West Midlands lagged other European automobile supply chains such as those in Germany and especially France (Bailey, 2003). Furthermore, it was recognised that too much of the supply base was low value- added 'metal bashing' and that higher value added production in areas such as electronics was needed (Bailey, 2003 p. 75). The modernisation programme of the RTF, with £17 million funding, sought to improve the competitiveness of the auto cluster through a 
range of measures. One of the most successful strategies was the use of the existing programme, Accelerate, to offer suppliers to Rover advice on new product and process development; grants for capital investment in plants for new products; and funds for the creation of supplier networks (House of Commons, 2006; Bailey 2003; Bailey and Kobayashi, 2006; Accelerate, 2002). The RTF also focused on the diversification of firms in the auto cluster into other 'clusters' with a long term aim to 'encourage the application of engineering skills in other industries such as medical and nano technologies' (Bailey, 2003, p.75). Some $£ 19.7$ million was used to assist with development costs, while the Small Business Service provided a diversification service.

Part of the diversification efforts of the RTF included a regeneration programme for the regional economy based on the development of "high-tech corridors" (Bailey and Kobayashi, 2006). The RTF commissioned several reports to identify innovative ways to diversify away from the automotive industry. One suggested the establishment of "high-tech" corridors that could capitalise on the region's existing science and technology base (SQW, 2001). The RTF1 Final Report recommended the establishment of three high technology corridors, one being the Central Technology Belt (CTB), running along the A38 and incorporating Birmingham University and Aston University, as well as the Longbridge site and the Queen Elizabeth hospital. The aim of the high technology corridors was to promote knowledge-intensive industries in the region (Rover, 2000; Bailey, 2003). Bailey has contended that a clusters approach was behind both the modernisation and diversification programmes and that 'the RDA was able to use the RTF to accelerate and legitimise this emerging clusters policy and to extend it further' (Bailey and Kobayashi, 2006, p.14). The adoption of the CTB and other high technology corridors enabled AWM to link clusters policies with spatial targeting (Bailey, 2003). The RTF's recommendation was supported by AWM in its 2004 Regional Economic Strategy (RES), as it was seen as a key mechanism for regional growth and the transition to a knowledge economy (see Ferrari in this issue). Some $£ 9$ million from the $£ 176$ million package of assistance offered in response to the closure of MG Rover in 2005 was set aside for investment in technology and innovation infrastructure in the three West Midlands high technology corridors. The RDA also received $£ 42$ million for redeveloping the Rover site (MG Rover, 2006). AWM established a company in 2004 to enact the Central Technology Belt strategy and this included the development of the Longbridge site, a feature of which will be the Longbridge Nano Materials Centre, which will be the UK hub for this technology.

The work of the Rover Task Force over the five years from 2000 contained the damage to the region when the automobile manufacturer closed (Armstrong, 2006, p.8, Bailey and Kobayashi, 2006). In the first phase the Supply Chain Diversification Scheme assisted 149 firms and helped save 1,500 jobs (Rover Taskforce, 2000; Bailey, 2003). The number of suppliers dependent on MG Rover fell from 161 firms in 2000 to 74 firms in 2005, with only 57 of those in the West Midlands (House of Commons, 2006). The MG Rover Taskforce noted that the supply chain was far better prepared to face the loss of MG Rover business than it had been in 2000 (MG Rover Taskforce, 2005a). The diverse efforts of AWM led to component suppliers shifting to other activities (House of Commons, 2006). Assessments made in 2000 estimated 24,000 jobs may have been lost should Rover close (House of Commons, 2006). In the end fewer than 
3,000 jobs were lost in the supply chain and supply chain closures were limited to just 11 businesses (MG Rover Task Force, 2005b, MG Rover Task Force, 2006, p.15). It is thought that the work of the Rover Task Force between 2000 and 2005 saved between 10,000 and 12,000 jobs (Bailey and Kobayashi 2006, House of Commons 2006).

\section{Responding to the Removal of MG Rover}

When MG Rover collapsed in 2005, the government moved quickly to establish a new MG Rover Task Force (RTF2) and provided a £176 million package of assistance. The RDA was the funding conduit for monies while also co-ordinating agencies such as Jobcentre Plus and the Learning Skills Council who were responsible for support to former workers (MG Rover Final Report, House of Commons 2006, House of Commons 2007 p.143).

The immediate assistance the RTF2 gave to suppliers played a critical role in limiting the impact on the regional economy. In the first instance government produced a £41.6 million package of measures to assist former suppliers of MG Rover to continue trading. This included a Wage Replacement Scheme which provided £50 per day for up to six weeks to assist firms continue operating and avoid retrenching staff. The Wage Replacement Scheme assisted 170 firms keep over 3,000 workers employed in the weeks following the collapse of MG Rover. This action saved an estimated 1,329 jobs (MG Rover Task Force, 2006 p.15). Loans were also given to firms who were affected by MG Rover's closure. The Transition Loan Fund assisted 17 companies with a total of $£ 5$ million (MG Rover Task Force, 2006 p.7). These measures proved highly successful in allowing businesses to continue, as well as limiting the impact of closure on the regional economy (House of Commons, 2006).

The RTF2 implemented a longer term programme of support that was based upon previous interventions, including the modernisation programme that was implemented through Accelerate and the diversification programme. There were three main elements to this 'Phase 2' support for suppliers which received $£ 9.6$ million of funding. The first was the development of a 'Productivity Alliance', which targeted 25 medium to large automotive companies who were either Tier 1 or Tier 2 suppliers. The aim was 'to improve their competitive position through increased productivity and up-skilling the workforce in a sustainable way' (MG Rover, 2006 p.19). The programme focussed on the dissemination of best practice with the hope that this would lead to improvements in quality, cost and delivery. The programme targeted companies that were long-term members of the supply chain and asked them to second suitable personnel for two years. It was hoped that these skills would be transferable beyond the automotive industry, thereby aiding company diversification and employee mobility (MG Rover, 2006 p.19). The second element was the Business Support Programme and it was aimed at 140 small to medium sized automotive companies. It sought to assist them develop and introduce innovative products; penetrate new markets; and gain business by improving their competitive position (MG Rover, 2006 p.20). Companies were able to procure specialist technical support from R\&D organisations and universities to assist in the design and development of new products. Thirdly an Innovation and Technology Support Programme was set up to encourage the take-up of innovation and technology in the automotive sector. Under this scheme Centres of Excellence were to be developed. The first two 
announced were in the areas of electronic reliability and design for niche vehicles. The overall goal of these policies was to keep the West Midlands region attractive to vehicle manufactures and Tier One suppliers by strengthening the supply base (MG Rover, 2006 pp.19-21). These policy interventions are important because, as Donnolly et al (2005) demonstrate, most small to medium firms in the auto sector in the West Midlands lack the capacity to invest in either R\&D or up-skilling.

\section{Labour Market Assistance}

The loss of jobs at MG Rover was of particular concern because unemployment rates in Birmingham and the West Midlands were higher than the national average and the manufacturing industry was already in decline (Armstrong, 2006; Cowling, 2005). In 2001 the West Midlands accounted for 20 per cent of jobs in manufacturing (DTI, 2001). Eighteen per cent of employment in the region was in manufacturing, five per cent more than the UK average (Cowling, 2005). The West Midlands was still seen as the heart of the automotive industry in Britain, with a large percentage of the automotive component sector located within the region (see Bailey et al in this issue). The potential impact of the closure of MG Rover was therefore considerable.

Recognising the importance of retaining the existing skills base in manufacturing in the region, AWM established a series of incentives for individuals to remain employed in manufacturing and for employers in the manufacturing industry to take on former MG Rover workers. Individuals were entitled to re-skilling to a minimum National Vocational Qualification (NVQ) Level 2 in a manufacturing skill and up to $£ 75$ pounds per week for 20 weeks to help those who had to travel long distances for new work. Employers who took on a displaced MG Rover worker were also entitled to have one other staff member trained to NVQ 2. A Manufacturing and Engineering Hub, or 'Skills Hub' was also established, providing a job matching scheme between redundant MG Rover workers and manufacturing businesses in the West Midlands. Employers who took on former MG Rover staff were covered for up-skilling costs as well as receiving a wage subsidy of $£ 50$ per week for 12 weeks. The MG Rover Taskforce reported that this service had a significant impact in helping ex-MG Rover workers obtain new employment. Direct intervention by Jobcentre Plus and the Learning Skills Council resulted in 751 displaced workers gaining new jobs through the Skills Hub (MG Rover Taskforce, 2006, pp. 12-13). These were important measures as the viability of manufacturing within the region depended on the retention of the skills base.

The most significant labour market intervention by government was the £50 million of funding set aside for training. Over 4,000 displaced MG Rover workers completed an individual skills advice session to develop their own Individual Training Plan. Of these, over 2,500 completed vocational training. The LSC also funded approximately 60 individuals to continue with or start a Higher Education programme (MG Rover Task Force, 2005b; House of Commons, 2006). Of the 4,000 individuals back in work, 1,111 received training (MG Rover Task Force, 2006). This is a substantial labour market intervention, especially when compared to the government response in Australia to the closure of Mitsubishi. However, Cowling and Isles have (2005) pointed out that the growth sectors in the regional economy public sector activities or high-technology industries that require a NVQ 
Level 3 or 4 . The economic position of the redeployed workers is therefore insecure unless further training is provided (House of Commons, 2007, Armstrong 2006). Moreover, as Ferrari and Burfitt point out in this issue, it is unlikely that former Rover workers will find employment in the knowledge intensive industries that the "high-tech" corridors hopes to create jobs in.

\section{POLICY RESPONSES TO EMPLOYMENT LOSS AT MITSUBISHI}

In April 2004 Mitsubishi Motors Australia Limited (MMAL) announced the loss of approximately 1,200 jobs in southern Adelaide through the closure of its Lonsdale site and redundancies from its Tonsley Park assembly plant. The closure was a profound shock to the region's economy, reducing Gross Regional Product by approximately \$(AUS) 1bn (Blandy 2004). It was also symbolically important because the two car manufacturing plants were icons of the region's economy and supported numerous suppliers, as well as many families within the region. As recently as the year 2000 the Lonsdale plant alone employed 2,000 workers while MMAL had 5,000 employees in total ${ }^{\text {iv }}$. The loss of employment at MMAL was symptomatic of broader changes in the Australian economy because while manufacturing has been, and remains, an important part of the Australian economy, the industry has declined as a consequence of economic liberalisation, including the reduction of tariff barriers. In the mid 1970s manufacturing employment accounted for 25 per cent of the workforce, but by 2001 it had declined to 12 per cent, even though the value of production had increased (Forster 2003). In South Australia the manufacturing sector still contributes 14 per cent of Gross State Product, 12 per cent of total employment and 62 per cent of total exports (Government of South Australia, 2006). Manufacturing represented 18 per cent of total employment in southern Adelaide at the 2001 Census, reflecting a high degree of dependency on this sector. Moreover, the region has been characterised by lower than average incomes, with a widening gap between average national incomes and those of the residents of the City of Marion and the City of Onkaparinga, the two councils that constitute the region (BITRA, 2007).

The strategic priorities of the Federal Government in responding to the loss of employment at Lonsdale were informed by the neoliberal philosophies that have characterised Australian Governments and their engagement with issues of economic development since the mid 1980s (Beer, et al 2005). Importantly, the Howard Coalition Government had not articulated a formal competitiveness strategy for Australian industry, nor had it recognised the potential impact of regional processes in shaping the wellbeing of businesses. Industry policy was couched in terms of an open, global, and competitive economy, with support for the car industry limited to a single, conventional, industry support programme. The Australian Government had previously committed \$2.4 billion over the period 2000-2005 as part of an industry-wide scheme, the Automotive Competitiveness Industry Scheme (ACIS). The State Government provided a range of more direct subsidies to MMAL. From a central government perspective, additional assistance was not justified when other industries were growing more rapidly. Governments adhered to the view that further substantial investment in the industry - and the affected manufacturer - would have had little impact, given the already substantial subventions. In consequence, both the State and Australian governments offered measured assistance in response to the 
closure of Mitsubishi and neither enunciated an explicit commitment to the well being of the affected region.

The Structural Adjustment Fund for South Australia

The Federal Government responded to the closure of Mitsubishi Lonsdale by announcing a $\$ 50$ million assistance package for the region (Media Release, $21^{\text {st }}$ May 2004). Some $\$ 40$ million of this package of support went to establishing the Structural Adjustment Fund for South Australia (SAFSA), a pooled fund into which the South Australian Government also committed \$5 million (Invest Australia, 2004). The SAFSA was the most significant response by either the Federal or State government to the loss of employment at MMAL and we must recognise that it does not fit easily within contemporary paradigms of regional development (Beer, et al. 2003) because the programme consisted of grants effectively capital subsidies - to firms willing to invest in South Australia. The SAFSA supported firms that were able to make a 'business case' that the injection of additional capital would allow for the expansion of business and would result in a significant number of new jobs. Critically, SAFSA monies were not targeted exclusively on the southern region of Adelaide but rather extended to all of South Australia. Furthermore, the grants did not focus on sectors in which the southern region of Adelaide could have developed a competitive advantage. Indeed, the minimum \$1 million investment criteria of the SAFSA ensured that most local businesses in the southern region were effectively excluded (City of Marion and City of Onkaparinga, 2005). SAFSA funding did not target hightechnology industries either. An examination of companies awarded grants shows most SAFSA funding went to low-technology and low-innovation businesses. The single largest grant was awarded to Ingham Enterprises to expand chicken processing in the north of Adelaide. Other substantial grants were awarded to a compost manufacturer and a food packaging company. Only \$4.8 million of the $\$ 45$ million SAFSA funding went into business expansions that could be considered 'high-tech'.

It could be argued that the lack of investment in innovation or the 'soft' infrastructure of innovation has not been significant as there has been regional growth through the creation of new businesses on the Lonsdale site. However, there has been a substantial loss of skills from the workforce as a result of the closure of MMAL's Lonsdale site; there is less employment on that site than previously and the value of manufacturing in the region has declined. Our research shows that 12 months post-redundancy, some 35 percent of former Mitsubishi workers were no longer participating in the labour force as they had retired, could not work because of a disability, or were unemployed (Beer, this issue). Furthermore, the absence of skills development meant that displaced workers were unable to take advantage of the growth in other sectors, such as defence and mining. One South Australian Government official remarked

"If you look at our manufacturing sector, large components have transitioned and, while we have had the odd shock in terms of downturn in the automotive sector, the economy has absorbed that incredibly well. It has almost been seamless, and those people get absorbed into the economy very, very quickly" (The Weekend Australian, 2007). 
However, the transition has not been as seamless given that a significant percentage of displaced workers remain unemployed, while others have 'exited' the labour force altogether. South Australia is now facing such a shortage of skilled labour that major projects in defence and mining could be impeded (The Advertiser, 2007). Furthermore, as with most programmes of this nature, SAFSA funding has not achieved the employment outcomes forecast (Haughton et al. 2003, Beer et al. 2003). The Federal Government acknowledged that the majority of firms who received grants have not achieved their employment targets. This led one newspaper to conclude that the $\$ 45$ million SAFSA was 'creating the wrong jobs in the wrong locations for the wrong people' (Nankervis and Castello, 2006).

Overall, SAFSA funding must be viewed as a relatively minor government intervention, especially when compared to the $£ 176$ million (the equivalent of approximately \$525 million Australian dollars) that the UK Government provided in response to MG Rover closing. The explanation for this parsimony lies in Federal and state governments who believed their interests lay in other sectors and other enterprises.

\section{The Mitsubishi Labour Adjustment Package}

The State Government of South Australia and the Federal Government jointly implemented the Mitsubishi Labour Adjustment Programme (LAP), delivered through the federally funded Job Network agencies ${ }^{\mathrm{v}}$. The Federal Government committed \$10 million to the LAP. Significantly the State Government did not commit funds, however the Department for Further Education, Employment, Science and Technology provided a range of services in support of the labour adjustment package (Hansard, $1^{\text {st }}$ May 2006, pp.8 and 27). These services included financial counselling, resume preparation and career counselling. State Government support totalled \$383,485, a modest amount given the scale of the redundancies and their expected impact on the southern region (Government of South Australia 2006 p.12).

The federally funded Mitsubishi LAP provided additional assistance to retrenched Mitsubishi employees, beyond the Job Search support normally provided to retrenched workers. The Mitsubishi LAP provided an additional \$450 per worker to Job Network providers so that they could purchase other assistance including tools, equipment, uniforms or training (DEWR 2006; Minister for Employment and Workplace Relations, 2004). Crucially funds were not set aside for retraining retrenched Mitsubishi workers, despite a skills shortage (Government of South Australia, 2005). Only 22 of the 936 individuals who registered for services were placed in full-time education lasting 12 months or more (Government of South Australia, 2006 p.12). Another study indicated that 59 percent of displaced workers reported that they had plans for further training which could assist their future employment (Beer et al, 2006 p.23). However, only five respondents reported they were full-time students, suggesting that the level of training amongst this group was low despite high interest. Within the Australian federal system such labour market interventions are a state responsibility. Arguably, an appropriate response from the South Australian Government was to set aside funds for the retraining of former Mitsubishi workers, liaising with Technical and Further Education, universities and other education providers to develop appropriate skills and training packages. Given 
the strong growth in the defence and mining industries there was an opportunity to provide training to assist former Mitsubishi workers enter these sectors. Indeed, one of the key recommendations of the recent House of Representatives Standing Committee (2006 p. 84) report into employment in the automotive and components industry was that future redundancies in the industry should have a labour adjustment programme that focused on 'targeted training to up-skill displaced workers into areas of skills needs'.

\section{INNOVATION AND REACTION: POLICY LESSONS ACROSS NATIONS}

Governments in the United Kingdom and Australia adopted contrasting policy settings in response to large-scale redundancies in automotive employment at Longbridge and Lonsdale. As the discussion above has shown, the British Government implemented innovative policies that in turn emphasised the building of long-term competitive advantage, the further development of the human capital of affected workers, locally or regionally focussed solutions to the challenge of redundancy and comprehensive measures to refocus the economy of the region. Critically, the UK Government's responses were founded on existing policy settings that embraced Porter's (1990) ideas of competitive advantage and recognised that the future of British manufacturing depended upon the development of high technology, knowledge intensive industries. The policy acknowledged that Britain lacked natural comparative advantages - such as resource endowments - and that the nation's long term economic future was dependent upon the skills and abilities of its workforce, as well as the presence of an innovative culture that accepted change and produced goods and services that were distinct on world markets. The responses of Australian governments to the loss of employment at MMAL stand in sharp relief to the policies and programmes implemented in the West Midlands: government interventions in Australia were reactive, they were not informed by a previously articulated philosophy of economic development and they concentrated on short term 'adjustment' rather than the longer term needs of the workforce and the region.

Critically, and unlike the UK, local or regional guidance of government responses was absent, with the package of assistance determined by central government and the allocation of funding to companies determined by a federally-constituted committee. While a regionally-based advisory committee was established in 2004 (Beer and Cooper, 2007), it had no influence on the distribution of Structural Adjustment Funds and modest influence on the reshaping of southern Adelaide's economy. Importantly, while the UK Government put in place a policy framework in 2000 that reduced the level of risk within the regional economy in the event of MG Rover's closure, no such strategy was in place in southern Adelaide in 2004, despite numerous predictions of the plant's closure over preceding years. Indeed, there is no evidence of such contingency planning even now, despite on-going media reports on the withdrawal of Mitsubishi Motors Australia Limited as a manufacturer ${ }^{\mathrm{vi}}$.

The British Government developed its policies for the realignment of the West Midlands economy in the knowledge that a successful manufacturing sector was central to the UK's on-going prosperity. In Australia strategic priorities have been placed elsewhere, especially in the growth of mining and some service industries. South Australia has embraced this change and while the state has been slow to develop its mineral resources when compared with Western Australia and 
Queensland, the growth potential is considerable. Through the development of new deposits and the application of technology, South Australia has the capacity to develop undeniable comparative advantage in the production of uranium, copper, iron ore, lead, silver and zinc. Moreover, it can do so with relatively modest public sector outlays when compared with the substantial funds invested by the UK Government in reconfiguring the West Midlands to a region of competitive advantage. Indeed, one of the critiques of the UK Government's actions following the closure of MG Rover was that not enough has been invested in some key policy domains, especially in funding the training of retrenched workers. This is despite the fact that the UK Government introduced a package of measures after the closure of Longbridge more than ten times the size of the Australian response to Lonsdale's demise and had previously invested an equal amount in anticipation of employment loss. The substantial costs of establishing sustainable competitive advantage remain unattractive to Australian Governments enamoured of neoliberal philosophies of government and attached to the notion that there are market-based solutions to virtually all questions of economy and society. The gulf between the policy settings evident in the UK and Australia is stark and in each instance the decisions of governments have established a degree of path dependency that will determine the long term future of the affected regions. In the West Midlands the challenge is to make a successful transition to a future based on advanced manufacturing and other high technology industries. The South Australian economy is set on a track focussed on large scale mining, while southern Adelaide - the region most affected by the loss of employment at MMAL - is likely to become more marginalised economically. Moreover, the economic future of the broader 'region' of South Australia must remain open to question as the mining sector remains subject to the vagaries of fickle international markets, has a low potential for value-adding, is intensely price competitive and requires little skilled labour.

Finally, it is important to acknowledge that the manner in which governments have chosen to respond in the UK and Australia to the loss of employment in the automotive sector - the $20^{\text {th }}$ Century industry par excellence - reflects the impact of differing paradigms of economic development. The UK response was informed by an adherence to the ideas of competitive advantage while Australia's response was developed within the intellectual framework of comparative advantage. Each perspective led to a distinct model for addressing the challenges of large scale redundancy. The UK model embraced the need for government intervention in the economy and resulted in a focus on encouraging innovation, improving the skills of the workforce, detailed planning and early intervention within the region. Despite the positive features of the approach used in the UK it is important to acknowledge the challenges that continue to confront the UK West Midlands (see Armstrong et al this issue). There is a need for further training support given the relatively low skill levels of workers leaving the manufacturing sector and the higher skill needs of emerging and growth sectors. In Australia, government action has more explicitly adopted the language and philosophies of neoliberalism and neoclassical economics, resulting in policies with a short term focus introduced in the absence of previous planning for structural change. Such an approach has been made possible by the presence of alternative economic opportunities within the state, coupled with the assumption - possibly illinformed - that labour markets and regional economies will adjust. In the medium to long term, the future of the West Midlands and southern Adelaide will 
reflect these competing paradigms of regional growth and keen observers of public policy should continue to track their relative fortunes in order to better comprehend the advantages and disadvantages of each.

\section{REFERENCES}

ADVANTAGE WEST MIDLANDS (1998) Regional Innovation Strategy and Action Plan: Shaping Our Future, Birmingham: Advantage West Midlands.

ADVANTAGE WEST MIDLANDS (1999) Creating Advantage: The West Midlands Economic Strategy, Birmingham: Advantage West Midlands.

ADVANTAGE WEST MIDLANDS (2004) Delivering advantage: The West Midlands Economic Strategy and Action plan 2004-2010, Birmingham: Advantage West Midlands.

ARMSTRONG, H. \& TAYLOR, J. (2000) Regional Economics and Policy, London: Blackwell.

ARMSTRONG, K. (2006) Life After MG Rover: The Impact of the Closure on the Workers, their Families and the Community, London: The Work Foundation.

BAILEY, D \& SUGDEN, R. (2007) Kūdōka, Restructuring and Possibilities for Industrial Policy in Japan, in D.BAILEY, D.COFFEY \& P.TOMLINSON, (eds), Crisis or Recovery in Japan? State and Industrial Economy, Cheltenham: Edward Elgar.

BAILEY, D. (2003) Globalisation, Regions and Cluster Policies: The Case of the Rover Task Force, Policy Studies, 2(3), p. 67-85.

BAILEY, D., \& KOBAYASHI, S. (2006) 'Life After Longbridge? Crisis and Restructuring in the West Midlands Auto Cluster', Institute for Economic Development Policy Discussion Paper. University of Birmingham.

BAWDEN, T. (2007) Serious Shortage of Hi-Tech Defence, Mining Workers, The Advertiser, May 22nd.

BEER, A. (2000) Regional Policy in Australia: Running out of Solutions?' in PRITCHARD B \& MCMANUS, P (ed.), Land of Discontent, Sydney: University of New South Wales Press.

BEER, A. CLOWER, T. HAUGHTON, G. \& MAUDE, A. (2005) Neoliberalism and the Institutions for Regional Development in Australia, Geographical Research, 43(1), p. 49-58.

BEER, A., \& COOPER, J. (2007) University-Regional Partnership in a Period of Structural Adjustment: Lessons from Southern Adelaide's Response to an Automobile Plant Closure, European Planning Studies, 15(8), p.1-22.

BEER, A., BAUM, F., THOMAS, H., LOWRY, D., CUTLER, C., ZHANG, G., JOLLEY, G., ZIERSCH, A., VERITY, F. \& MACDOUGALL, C. (2006) An Evaluation of the Impact of Retrenchment At Mitsubishi Focusing on Affected Workers, Their Families and Communities: Implications for Human Services Policies and Practices, Final Report to Department of Health, Adelaide: Flinders University.

BEER, A., HAUGHTON, G. \& MAUDE, A. (2003) Developing Locally: Lessons in Economic Development from Four Nations, Bristol: Policy Press.

BEER, A., MAUDE, A. \& PRITCHARD, B. (2003) Developing Australia's Regions: Theory and Practice, Sydney: University of NSW Press.

BLANDY, R. (2004) A Quantitative Assessment of the Southern Economy and the Effects of the Closures of the Mobil and Mitsubishi Plants at Lonsdale and 
Tonsley Park together with an Outline of a Strategic Response, Commissioned by the City of Onkaparinga and the City of Marion.

BUITER, W H \& MILLER, M. (1981) Monetary Policy and International Competitiveness: The Problem of Adjustment, in W A ELTIS \& $\mathrm{P} J \mathrm{~N}$ SINCLAIR, eds, The Money Supply and the Exchange Rate, Oxford: OUP.

BUREAU OF TRANSPORT, INFRASTRUCTURE \& REGIONAL ECONOMICS (2007) Regional Economic Growth, BITRE's Taxable Income Database, Canberra: BITRE.

CITY OF MARION \& CITY OF ONKAPARINGA (2005) Southern Region Economic Diversification Plan Draft 2.

CITY OF MARION \& CITY OF ONKAPARINGA (2007) Think South: A new Economic Future.

COOKE, P. \& MORGAN, K. (2000) The Associational Economy, Oxford: Oxford University Press.

COURVISANOS, J. (2003) Innovation for regional communities: A research framework, Paper presented to the Sustainable Economic Growth for Regional Australia Conference, Gold Coast, Unpublished.

COWLING, M., \& ILES, N. (2005) Sent to Coventry? The Re-employment of the Longbridge 5000, London: The Work Foundation.

DEPARTMENT OF EMPLOYMENT \& WORKPLACE RELATIONS (2006b) Supplementary Submission to the Inquiry into Employment in the Component Manufacturing Sector, Adelaide.

DEPARTMENT OF EMPLOYMENT \& WORKPLACE RELATIONS, (2006a) Submission to the Inquiry into Employment in the Component Manufacturing Sector, Adelaide.

DEPARTMENT OF INDUSTRY, TOURISM \& RESOURCES (2002) Media Release, 'Car Industry to Benefit From Mitsubishi'.

DEPARTMENT OF INDUSTRY, TOURISM \& RESOURCES (2003) Media release, 'Eight New Projects to Invest \$53 Million in South Australia'.

DEPARTMENT OF PRIME MINISTER \& CABINET (2004) Media release, 'Mitsubishi \$50 Million Federal Assistance Package'.

DEPARTMENT OF TRADE \& ECONOMICS (2001) Business Clusters in the UK- A first Assessment, 1\&2, London: The Stationary Office.

DEPARTMENT OF TRADE \& INDUSTRY (1994) Competitiveness: Helping Business to Win, London: HMSO.

DEPARTMENT OF TRADE \& INDUSTRY (1995) Competitiveness: Forging Ahead, London: HMSO.

DEPARTMENT OF TRADE \& INDUSTRY (1998) Our Competitive Future: Building the Knowledge Driven Economy. London: The Stationery Office.

DEPARTMENT OF TRADE \& INDUSTRY (2001) Business Clusters in the UK- A First Assessment, London: The Stationery Office.

DONNOLLY, T. BARNES, S. \& MORRIS, D. (2005) Restructuring the Automotive Industry in the English West Midlands, Local Economy, 20(3), August 2005.

EASTWOOD, R K \& VENABLES, A. (1982) The Macroeconomic Implications of a Resource Discovery in an Open Economy, Economic Journal, 92, p. 825-48.

FFOWCS WILLIAMS, I. (2004) Cluster Development: Red Lights and Green Lights, Sustaining Regions, 4(2), p. 24-33.

FORSTER, C. (2003) Australian Cities, Continuity and Change, 3rd ed., Oxford: Oxford University Press. 
GARNAUT, R. (1998) Australian Cars in a Global Economy, The Australian Economic Review, 30(4), p. 359-73.

GAVRON, R., COWLING, M., HOLTHAM, G., \& WESTALL, A. (1998) The Entrepreneurial Society, London: Institute for Public Policy Research.

GOVERNMENT OF SOUTH AUSTRALIA (2005) Global Horizons, Local Initiatives: A Framework for South Australia's Manufacturing Future, Adelaide.

GOVERNMENT OF SOUTH AUSTRALIA, (2006) Submission to the House of Representatives Standing Committee Inquiry into Employment in Automotive Component Manufacturing, Adelaide.

HAUGHTON, G., BEER, A. \& MAUDE, A. (2003) Understanding International Divergence and Convergence in Local and Regional Economic Development, p. 15-36 in Beer A. et al (eds) Developing Locally: An International Comparison of Local and Regional Economic Development, Bristol: Polity Press.

HOUSE OF COMMONS (2006) The Committee of Public Accounts, The Closure of MG Rover. Report, Together with Formal Minutes, Oral and Written Evidence, HC10013., London: The Stationary Office Ltd.

HOUSE OF COMMONS. TRADE \& INDUSTRY COMMITTEE (2007) Success and Failure in the UK Car Manufacturing Industry Fourth Report of the Session 2006-07, London: The Stationary Office, March 2007.

HOUSE OF REPRESENTATIVES STANDING COMMITTEE ON EMPLOYMENT, WORKPLACE RELATIONS \& WORKFORCE PARTICIPATION (2006) Shifting Gears: Employments in the Automotive Components Manufacturing Industry, Canberra: Commonwealth of Australia.

HOUSE OF REPRESENTATIVES, STANDING COMMITTEE ON EMPLOYMENT, WORKPLACE RELATIONS \& WORKFORCE PARTICIPATION (2006) Official Committee Hansard, 1st May.

INVEST AUSTRALIA (2004) Structural Adjustment Fund for South Australia: Ministerial Guidelines, Canberra.

KRUGMAN, P. (1996) Making Sense of the Competitiveness Debate, Oxford Review of Economic Policy, 12(3), p. 17-25.

MG ROVER TASK FORCE (2005a) Closure of MG Rover: Economic Impact Assessment, Paper prepared for submission to the Department for Trade and Industry, Birmingham: Advantage West Midlands.

MG ROVER TASK FORCE (2005b) Six Months On, Paper Prepared for Submission to the Department for Trade and Industry, Birmingham: Advantage West Midlands.

MG ROVER TASK FORCE (2006) Final Update Report: The Work Goes On, paper prepared for submission to the Department of Trade and Industry, Birmingham: Advantage West Midlands.

MINISTER FOR EMPLOYMENT \& WORKPLACE RELATIONS (2004) \$10 million Labour Adjustment Package for Mitsubishi Workers, 21st May.

MINISTER FOR EMPLOYMENT \& WORKPLACE RELATIONS (2004) 'Job Network Ready to Help Retrenched Mitsubishi Workers', 25th June.

NANKERVIS, D. \& COSTELLO, R. (2006) 'South Missing Out on \$45 Million Car Fund', The Sunday Mail, 17th December.

NEARY, J.P. \& VAN WIJNBERGEN, S. (1984) Can Higher Oil Revenues Lead to a Recession? A comment on Eastwood and Venables, Economic Journal, 94, p. 390-5.

OUGHTON, C. (1997) Competitiveness Policy in the 1990s, The Economic Journal, 107, no 444. 
PORTER, M. (1990) The Competitive Advantage of Nations, London: Macmillan.

PORTER, M. (1998a) Competitive Advantage: Creating and Sustaining Superior Performance, New York: Free Press.

PORTER, M. (1998b) Clusters and the New Economics of Competition, Harvard Business Review, 76, p. 77-90.

PORTER, M. (2003) The Economic Performance of Regions, Regional Studies, 37, p. 549-578.

PORTER, M. \& KETELS, H M. (2003) UK Competitiveness: Moving to the Next Stage, DTI Economics Paper, No.2, London: DTI.

PORTER, M.E., HIROTAKA T. \& SAKAKIBARA, M. (2000) Can Japan Compete? New York: Basic Books.

RICARDO, D. (1817) On the Principles of Political Economy and Taxation, London: John Murray.

ROBERTS, B. \& ENRIGHT, J. (2004) Industry Clusters in Australia: Recent Trends and Prospects, European Planning Studies, 12(1), p. 99-122.

ROVER TASK FORCE (2000) Final Report and Recommendations to the Secretary of State for Trade and Industry, Birmingham: Advantage West Midlands.

SCOTT, A. (2004) A Qualitative Assessment of Opportunities for Infrastructure and Industry Development to Counter the Effects of the closure of Mobil and the Mitsubishi Plant at Lonsdale on the Southern Region of Adelaide, Report Commissioned by the City of Onkaparinga and the City of Marion.

SPOEHR, J. (2005) The State of South Australia, South Australia: Wakefield Press.

SQW (2001) Regenerating the West Midlands Region- A Study To Consider Opportunities for High Technology Corridors/Clusters, Birmingham: Advantage West Midlands.

THE ADVERTISER (2007) Rann: We Won't Prop Up Industry, 4th July. THE WEEKEND AUSTRALIAN (2007) 'South Australia: On the Move', May 12-13th, p. 1-12.

WHITFORD, J. \& ENRIETTI, A. (2005) 'Surviving the Fall of a King: The Regional Institutional Implications of Crisis at Fiat Auto', International Journal of Urban and Regional Research, 29(4), p.771-795.

WREN (2001) The Industrial Policy of Competitiveness: a Review of Recent Developments in the UK, Regional Studies, 35(9), p. 847-860.

\footnotetext{
${ }^{\mathrm{i}}$ This paper reports on research funded by the Australian Research Council Linkage Grant LP0562288 and ESRC Grant RES-000-22-2478. We would also like to acknowledge the assistance of Mrs Cecile Cutler in proof reading the text.

ii School of Geography, Population and Environmental Management, Flinders University, Adelaide. Contact: Andrew.beer@flinders.edu

iii Birmingham Business School, UK. Contact: d.g.bailey@bham.ac.uk

${ }^{\text {iv }}$ At the time of revising this paper (March 2008) the last MMAL plant is about to close with the loss of 980 jobs.

${ }^{\mathrm{v}}$ The Job Network is a national network of private and community organisations who receive Federal Government funding to provide employment assistance

${ }^{\mathrm{vi}}$ Which has subsequently come to realisation.
} 